Prepared in cooperation with the Federal Highway Administration

\title{
Bridge Scour Countermeasure Assessments at Select Bridges in the United States, 2016-18
}

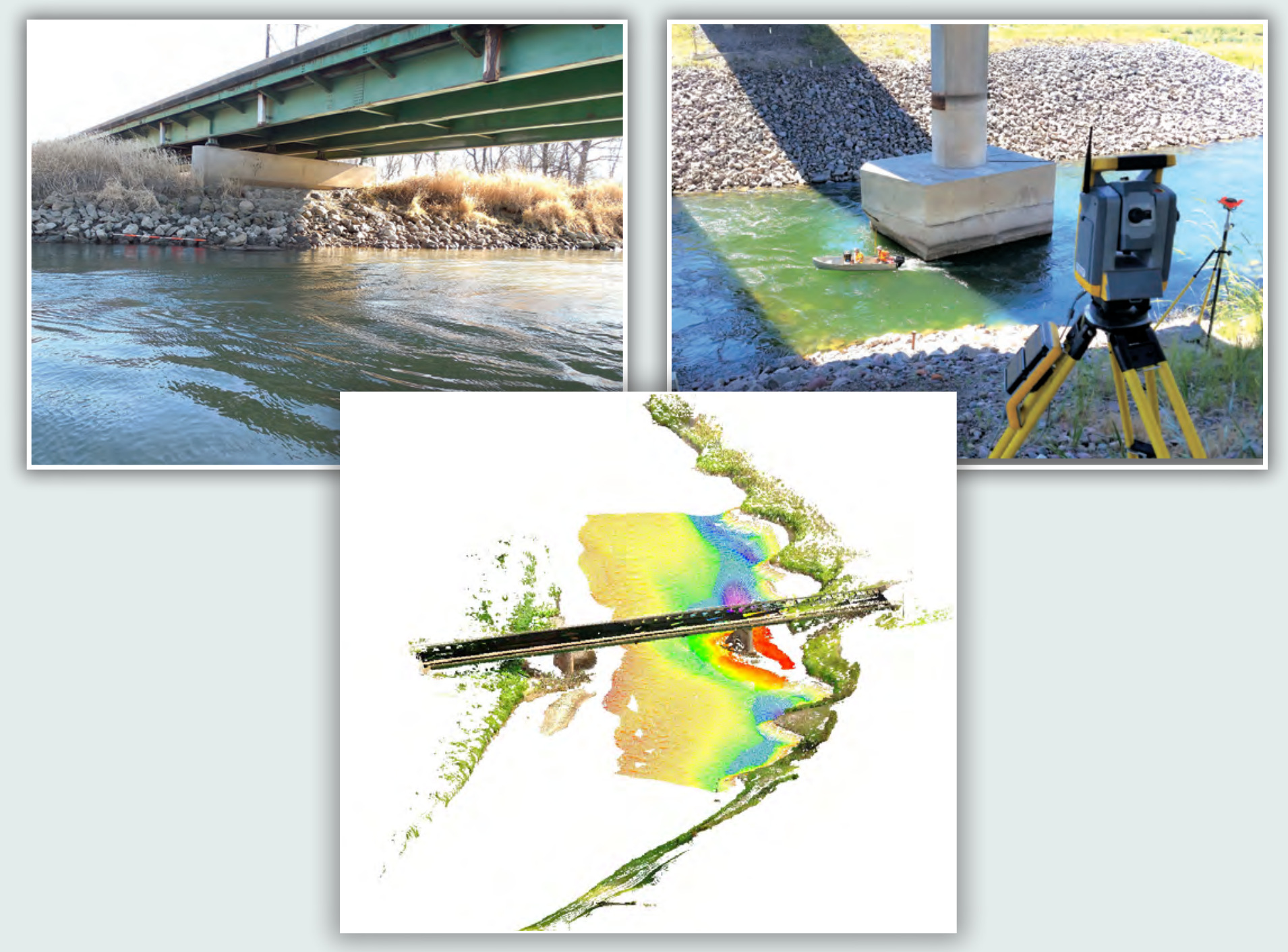

Open-File Report 2019-1008 
Cover:

Banner:

T-LiDAR survey being conducted during the November 2015 site visit at the Grand River near McFall, Missouri (site ID 011). Photograph by Richard Huizinga.

Top left:

Conducting Wolman pebble count on riprap on left bank at the Wapsipinicon River near Wheatland, lowa (site ID 031). Photograph by Richard Huizinga.

Top right:

Photograph showing singlebeam bathymetric survey being conducted during the June 2016 site visit using Trimble S6 total station scanner at the Blackfoot River near Bonner, Montana (site ID 016). Photograph by Taylor Dudunake.

Bottom:

High-resolution bathymetric point cloud and T-LiDAR data obtained by Richard Huizinga during the August 2018 site visit at the Upper lowa River near Dorchester, lowa (site ID 030). 


\section{Bridge Scour Countermeasure Assessments at Select Bridges in the United States, 2016-18}

By Taylor J. Dudunake, Richard J. Huizinga, and Ryan L. Fosness

Prepared in cooperation with the Federal Highway Administration

Open-File Report 2019-1008

U.S. Department of the Interior

U.S. Geological Survey 


\title{
U.S. Department of the Interior DAVID BERNHARDT, Acting Secretary
}

\author{
U.S. Geological Survey \\ James F. Reilly II, Director
}

U.S. Geological Survey, Reston, Virginia: 2019

For more information on the USGS—-the Federal source for science about the Earth, its natural and living resources, natural hazards, and the environment-visit https://www.usgs.gov/ or call 1-888-ASK-USGS (1-888-275-8747).

For an overview of USGS information products, including maps, imagery, and publications, visit https://store.usgs.gov.

Any use of trade, firm, or product names is for descriptive purposes only and does not imply endorsement by the U.S. Government.

Although this information product, for the most part, is in the public domain, it also may contain copyrighted materials as noted in the text. Permission to reproduce copyrighted items must be secured from the copyright owner.

Suggested citation:

Dudunake, T.J., Huizinga , R.J., and Fosness, R.L., 2019, Bridge scour countermeasure assessments at select bridges in the United States, 2016-18: U.S. Geological Survey Open-File Report 2019-1008, 12 p., https://doi.org/10.3133/ofr20191008.

ISSN 2331-1258 (online) 


\section{Contents}

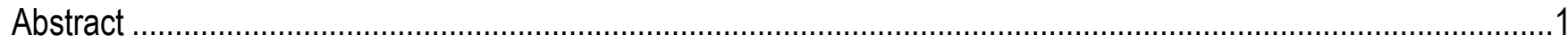

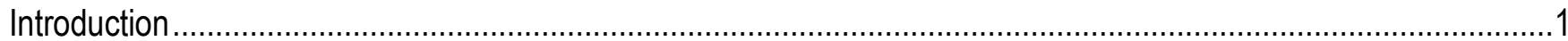

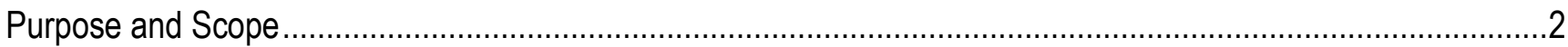

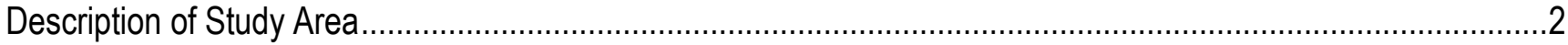

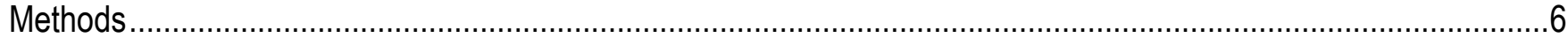

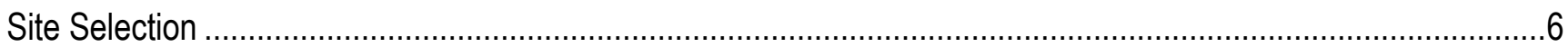

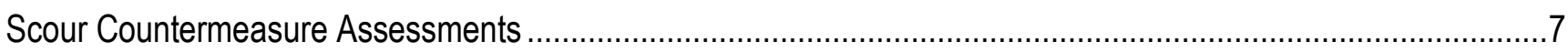

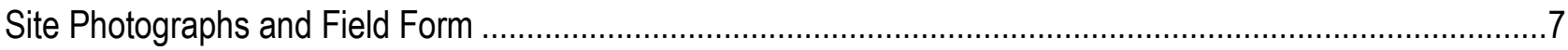

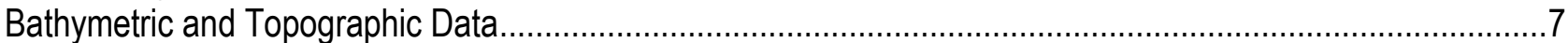

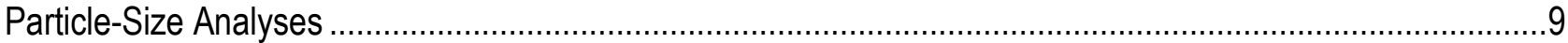

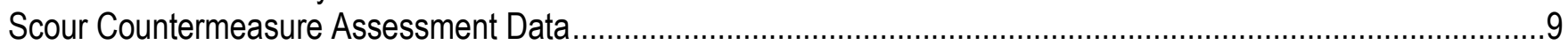

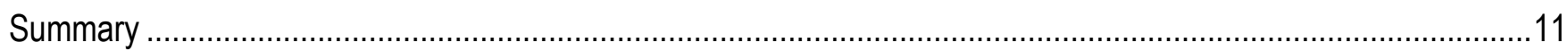

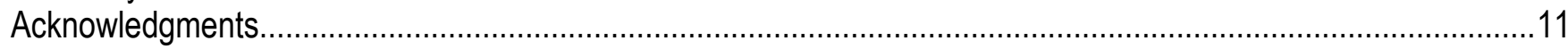

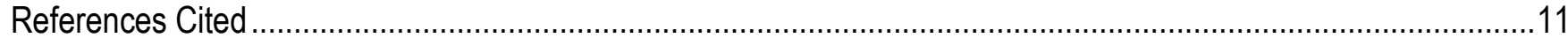

\section{Figure}

Figure 1. Map showing sites of the assessment of scour-related countermeasures at representative bridges throughout the United States, 2016-18

\section{Tables}

Table 1. Description of approved sites, assessment category, and post-countermeasure hydrologic summary with collected data throughout the United States, 2016-18 3

Table 2. References for various data-collection techniques of category 1-9 sites . 8

Table 3. Survey sites and links to particle-size analysis data for the assessment of scour-related countermeasures at representative bridges in United States, 2014-2018 


\section{Conversion Factors}

Inch/Pound to International System of Units

\begin{tabular}{lcl}
\hline Multiply & By & \multicolumn{1}{c}{ To obtain } \\
\hline cubic foot per second $\left(\mathrm{ft}^{3} / \mathrm{s}\right)$ & Flow rate & \\
\hline & 0.02832 & cubic meter per second $\left(\mathrm{m}^{3} / \mathrm{s}\right)$ \\
\hline foot $(\mathrm{ft})$ & Length & meter $(\mathrm{m})$ \\
mile $(\mathrm{mi})$ & 0.3048 & kilometer $(\mathrm{km})$ \\
\hline
\end{tabular}

\section{Datums}

Vertical coordinate information is referenced to the North American Vertical Datum of 1988 (NAVD 88).

Horizontal coordinate information is referenced to the North American Datum of 1983 (NAD 83).

Elevation, as used in this report, refers to distance above the vertical datum.

\section{Abbreviations}

$\begin{array}{ll}\text { AEP } & \text { annual exceedance probability } \\ \text { DOT } & \text { Department of Transportation } \\ \text { FHWA } & \text { Federal Highway Administration } \\ \text { MBES } & \text { multibeam echo sounder } \\ \text { NBI } & \text { National Bridge Inventory } \\ \text { NWIS } & \text { National Water Information System } \\ \text { OFR } & \text { Open File Report } \\ \text { RI } & \text { recurrence interval } \\ \text { RTK-GNSS } & \text { real-time kinematic-global navigation satellite system } \\ \text { SBES } & \text { singlebeam echosounder } \\ \text { T-LiDAR } & \text { terrestrial light detection and ranging technology } \\ \text { USGS } & \text { U.S. Geological Survey }\end{array}$




\title{
Bridge Scour Countermeasure Assessments at Select Bridges in the United States, 2016-18
}

\author{
By Taylor J. Dudunake, Richard J. Huizinga, and Ryan L. Fosness
}

\begin{abstract}
In 2009, the Federal Highway Administration published Hydraulic Engineering Circular No. 23 (HEC-23) to provide specific design and implementation guidelines for bridge scour and stream instability countermeasures. However, the effectiveness of countermeasures implemented over the past decade following those guidelines has not been evaluated. Therefore, in 2013, the U.S. Geological Survey, in cooperation with the Federal Highway Administration, began a study to assess the current condition of bridge-scour countermeasures at selected sites to evaluate their effectiveness. Bridge-scour countermeasures were assessed during 2016-2018 after additional sites were added following a similar study. Site assessments included reviewing countermeasure design plans, summarizing the peak and daily streamflow history, and assessments at each site. Each site survey included a photo log summary, field form, and topographic and bathymetric geospatial data and metadata. This report documents the study area and site-selection criteria, explains the survey methods used to evaluate the condition of countermeasures, and presents the complete documentation for each countermeasure assessment.
\end{abstract}

\section{Introduction}

On April 5, 1987, 10 people lost their lives as a result of the failure of a New York State Thruway bridge over Schoharie Creek (Lumia, 1998). The cause of the failure was erosion of the channel bed material, or scouring, under pier 3, which supported two of the five bridge spans (National Transportation Safety Board, 1988). According to the Federal Highway Administration (FHWA), scouring around bridge foundations is the most common cause of bridge failure (Federal Highway Administration, 2012). This risk can be mitigated by implementing effective bridge-scour countermeasures.

Bridge-scour countermeasures minimize risk to public transportation infrastructure by reducing sediment scour at bridges. Countermeasures can be defined as structures incorporated into a highwaystream crossing system that control or minimize harmful stream instability and/or bridge-scour (Federal Highway Administration, 2009). In 2009, the FHWA published the Hydraulic Engineering Circular No. 23 (HEC-23; Federal Highway Administration, 2009) to provide specific design and implementation guidelines for bridge scour and stream instability countermeasures. However, the effectiveness of countermeasures implemented over the past decade following FHWA HEC-23 guidelines has not been evaluated. Therefore, in 2013, the U.S. Geological Survey (USGS), in cooperation with the FHWA, began a study to assess the current condition of bridge-scour countermeasures at 20 select sites across the United States. The FHWA will use these site-specific assessments to evaluate the effectiveness of bridge-scour countermeasures described in the HEC-23 design guidelines. 


\section{Purpose and Scope}

This report summarizes countermeasure site assessments conducted in 2016 through 2018 at selected sites across the United States. Site assessments included reviewing countermeasure design plans, summarizing the peak and daily streamflow history, and a site survey to document the existing site and countermeasure. This report presents the complete documentation for each countermeasure assessment. Dudunake and others (2017) summarizes the initial phase of this project and included countermeasure assessments for 14 bridge sites. This report summarizes the second phase of a longer term study (Dudunake and others, 2017).

This report documents the study area and site-selection criteria, explains the survey methods used to evaluate the condition of countermeasures, and presents site assessments summarizing the countermeasure condition.

\section{Description of Study Area}

The study area in this report includes 20 bridge sites in 8 States: Connecticut, Idaho, Iowa, Missouri, Montana, New Jersey, Pennsylvania, and South Carolina (fig. 1, table 1). These bridge sites vary in river and bridge size, magnitude of flow, and type of countermeasures.

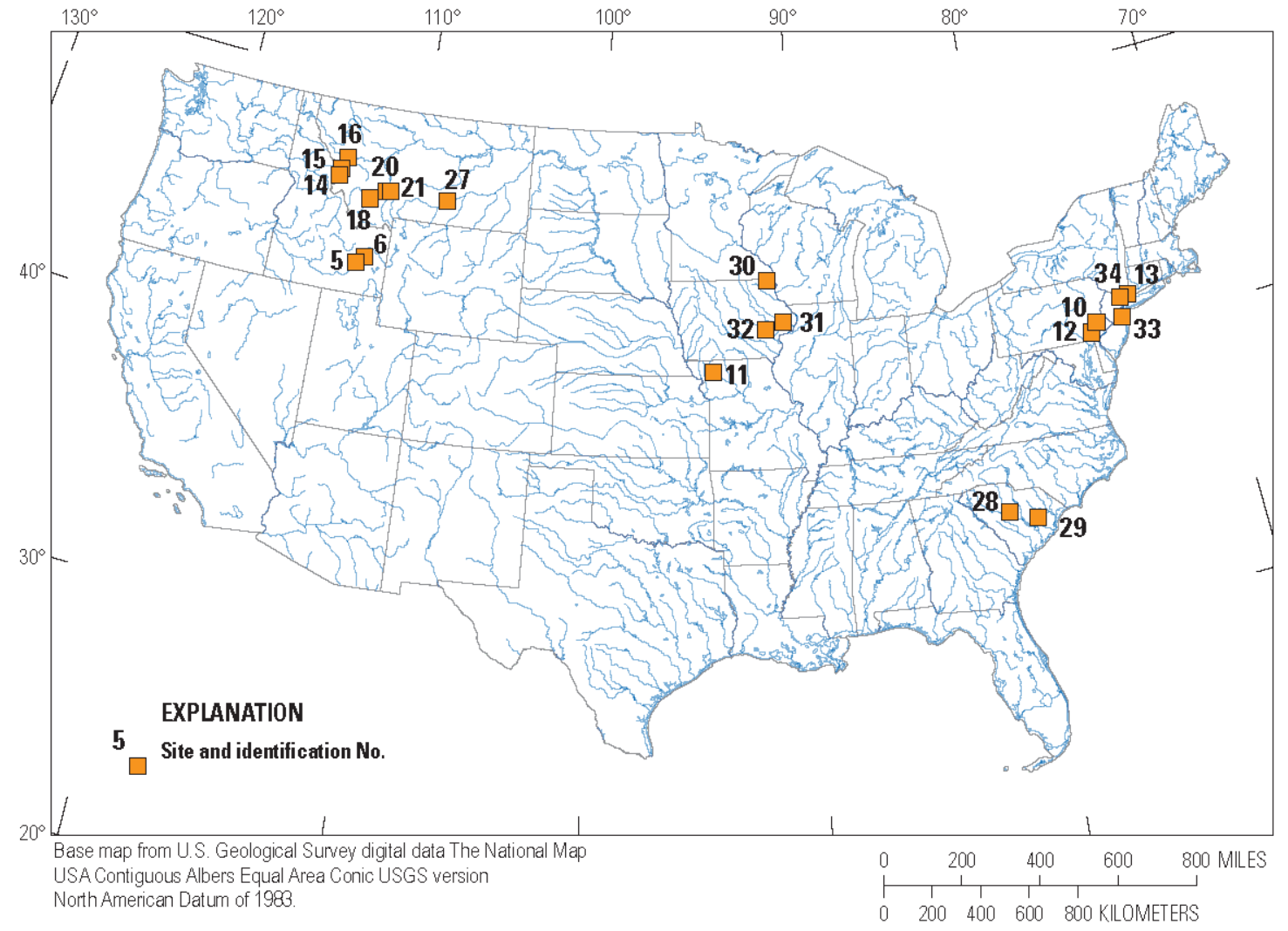

Figure 1. Map showing sites of the assessment of scour-related countermeasures at representative bridges throughout the United States, 2016-18. 
Table 1. Description of approved sites, assessment category, and post-countermeasure hydrologic summary with collected data throughout the United States, 2016-18.

[Year countermeasure installed: Countermeasure installation data not documented for each day, month, or both. Abbreviations: NBI, National Bridge Inventory; dd, decimal degrees; $\mathrm{ft}^{3} / \mathrm{s}$, cubic feet per second; AEP, annual exceedance probability; CT, Connecticut; IA, Iowa; ID, Idaho; IL, Illinois; MO, Missouri; MT, Montana; NJ, New Jersey; PA, Pennsylvania; SC, South Carolina]

\begin{tabular}{|c|c|c|c|c|c|c|c|c|c|c|}
\hline $\begin{array}{l}\text { Site } \\
\text { No. }\end{array}$ & NBI structure No. & Site name & $\begin{array}{l}\text { Latitude } \\
\text { (dd) }\end{array}$ & $\begin{array}{l}\text { Longitude } \\
\text { (dd) }\end{array}$ & $\begin{array}{l}\text { Survey } \\
\text { category }\end{array}$ & $\begin{array}{l}\text { Represent- } \\
\text { ative } \\
\text { streamgage }\end{array}$ & $\begin{array}{l}\text { Year } \\
\text { counter- } \\
\text { measure } \\
\text { installed }\end{array}$ & $\begin{array}{l}\text { Peak-flow } \\
\text { post-counter- } \\
\text { measure } \\
\left(\mathrm{ft}^{3} / \mathrm{s}\right)\end{array}$ & $\begin{array}{l}\text { Year of peak flow } \\
\text { post-counter- } \\
\text { measure }\end{array}$ & $\begin{array}{l}\text { Peak-flow, } \\
\text { post-counter- } \\
\text { measure, AEP } \\
\text { (percent) }\end{array}$ \\
\hline 005 & 000000000019340 & $\begin{array}{l}\text { Snake River at } \\
\text { Ferry Butte } \\
\text { Road (W } 500 \\
\text { S), Bingham } \\
\text { County, ID }\end{array}$ & 43.1269 & -112.5133 & 1 & 13069500 & 2002 & 28,700 & 2011 & ${ }^{1} 20$ \\
\hline 006 & 000000000019275 & $\begin{array}{l}\text { Snake River at } \\
\text { Shelley West } \\
\text { River Road (E } \\
1250 \text { N) near } \\
\text { Shelley, ID }\end{array}$ & 43.3767 & -112.1694 & 1 & 13060000 & 2002 & 32,300 & 2011 & ${ }^{1} 10$ \\
\hline 010 & $\begin{array}{l}000000000047594 \\
0000000000475 \\
95\end{array}$ & $\begin{array}{l}\text { Perkiomen Creek } \\
\text { and Mill Race } \\
\text { at Salford } \\
\text { Station Road } \\
\text { (SR 1024) near } \\
\text { Perkiomenville, } \\
\text { PA }\end{array}$ & 40.2984 & -75.4574 & 8 & 01473000 & 2012 & 26,600 & 2011 & 2 \\
\hline 011 & 7583 & $\begin{array}{l}\text { Grand River at } \\
\text { Rte-A (P0250) } \\
\text { near McFall, } \\
\text { MO }\end{array}$ & 40.1128 & -94.2975 & 4 & 06897500 & 2001 & 55,000 & 2007 & 1 \\
\hline 012 & 000000000010536 & $\begin{array}{l}\text { West Branch } \\
\text { Brandywine } \\
\text { Creek at } \\
\text { Strasburg Road } \\
\text { (SR 3062) near } \\
\text { Coatesville, PA }\end{array}$ & 39.9467 & -75.7800 & 8 & 01480617 & 2008 & 7,000 & 2014 & 10 \\
\hline
\end{tabular}




\begin{tabular}{|c|c|c|c|c|c|c|c|c|c|c|}
\hline $\begin{array}{l}\text { Site } \\
\text { No. }\end{array}$ & NBI structure No. & Site name & $\begin{array}{l}\text { Latitude } \\
\text { (dd) }\end{array}$ & $\begin{array}{l}\text { Longitude } \\
\text { (dd) }\end{array}$ & $\begin{array}{l}\text { Survey } \\
\text { category }\end{array}$ & $\begin{array}{l}\text { Represent- } \\
\text { ative } \\
\text { streamgage }\end{array}$ & $\begin{array}{l}\text { Year } \\
\text { counter- } \\
\text { measure } \\
\text { installed }\end{array}$ & $\begin{array}{l}\text { Peak-flow } \\
\text { post-counter- } \\
\text { measure } \\
\left(\mathrm{ft}^{3} / \mathrm{s}\right)\end{array}$ & $\begin{array}{c}\text { Year of peak flow } \\
\text { post-counter- } \\
\text { measure }\end{array}$ & $\begin{array}{l}\text { Peak-flow, } \\
\text { post-counter- } \\
\text { measure, AEP } \\
\text { (percent) }\end{array}$ \\
\hline 013 & 05018 & $\begin{array}{l}\text { Byram River at } \\
\text { Sherwood Ave } \\
(05018) \text { at } \\
\text { Greenwich, CT }\end{array}$ & 41.0609 & -73.6775 & 8 & 01212500 & 2010 & 1,700 & 2011 & 10 \\
\hline 014 & $\mathrm{P} 00007043+06661$ & $\begin{array}{l}\text { Bitterroot River at } \\
\text { US-93 near } \\
\text { Hamilton, MT }\end{array}$ & 46.1987 & -114.1684 & 8 & 12344000 & 2004 & 12,000 & 2009 & 10 \\
\hline 015 & S00370000+05361 & $\begin{array}{l}\text { Bitterroot River at } \\
\text { Bell Crossing } \\
\text { near Victor, } \\
\text { MT }\end{array}$ & 46.4435 & -114.1242 & 3 & 12350250 & 2004 & 13,700 & 2011 & 20 \\
\hline 016 & I00090110+01981 & $\begin{array}{l}\text { Blackfoot River at } \\
\text { I-90 at Bonner, } \\
\text { MT }\end{array}$ & 46.8717 & -113.8869 & 3 & 12340000 & 2004 & 17,200 & 2011 & 4 \\
\hline 018 & $\mathrm{P} 00049027+05411$ & $\begin{array}{l}\text { Beaverhead River } \\
\text { at MT- } 41 \text { at } \\
\text { Twin Bridges, } \\
\text { MT }\end{array}$ & 45.5443 & -112.3325 & 8 & $\begin{array}{l}06023100 \\
06026500\end{array}$ & 2009 & 3,100 & 2011 & ${ }^{1} 10$ \\
\hline 020 & P00013093+06931 & $\begin{array}{l}\text { Jefferson River at } \\
\text { MT-2 near } \\
\text { Three Forks, } \\
\text { MT }\end{array}$ & 45.8969 & -111.5963 & 8 & 06036650 & 2008 & 17,700 & 2011 & 4 \\
\hline 021 & I00090278+08571 & $\begin{array}{l}\text { Madison River at } \\
\text { I-90 near Three } \\
\text { Forks, MT }\end{array}$ & 45.8986 & -111.5237 & 8 & 06041000 & 2004 & 8,050 & 2011 & 10 \\
\hline 027 & L56788012+07001 & $\begin{array}{l}\text { Yellowstone } \\
\text { River at Hwy } \\
312 \text { at Huntley, } \\
\text { MT }\end{array}$ & 45.9039 & -108.3186 & 3 & 06214500 & 2008 & 73,700 & 2011 & 4 \\
\hline 028 & 000000000009360 & $\begin{array}{l}\text { Smith Branch at } \\
\text { S-126 (Clement } \\
\text { Rd) at } \\
\text { Columbia, SC }\end{array}$ & 34.0350 & -81.0600 & 6 & 02162093 & 1998 & 5,030 & 2015 & $<0.2$ \\
\hline
\end{tabular}




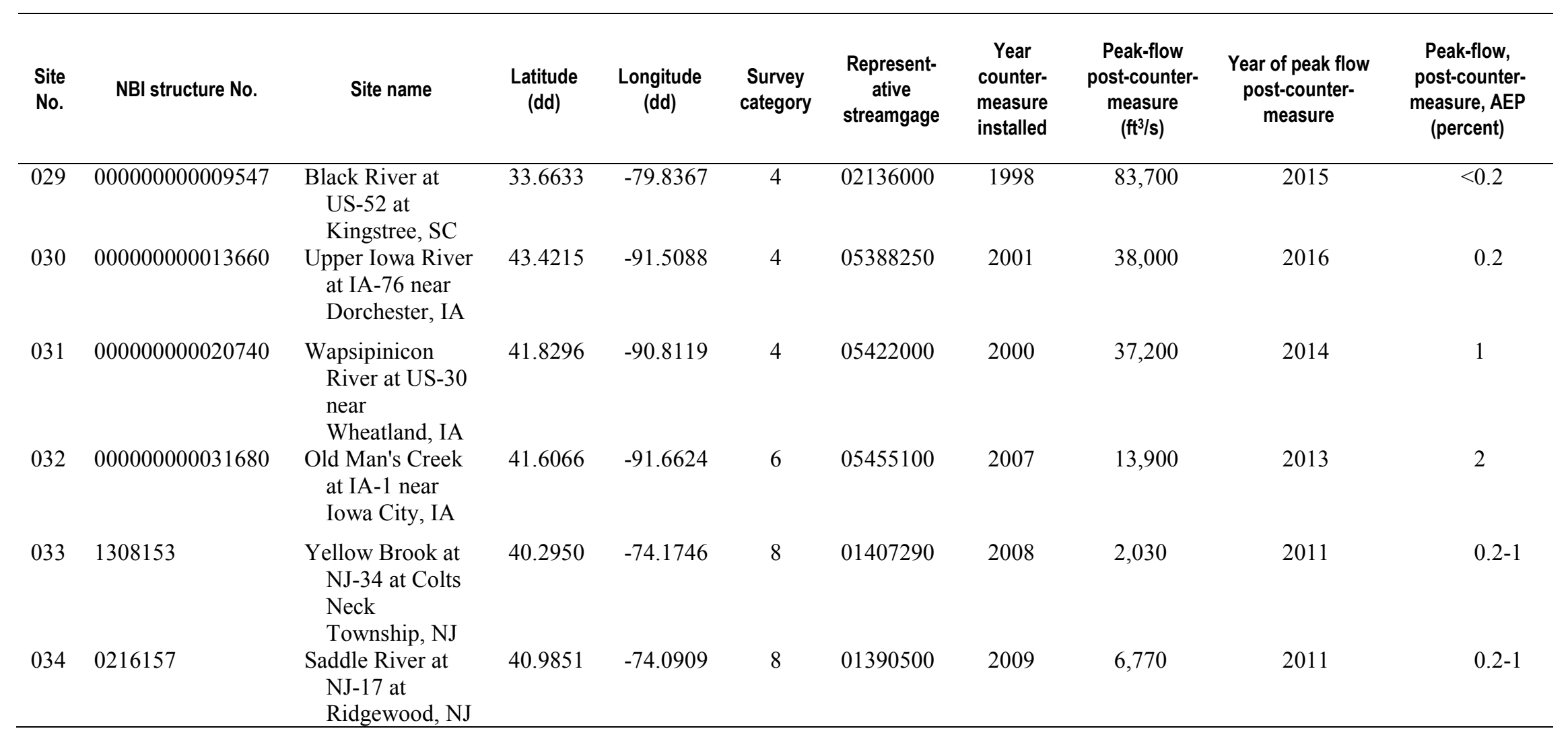

${ }^{1}$ Estimate affected to unknown degree by upstream regulation. 


\section{Methods}

To date, there has been no comprehensive evaluation of the effectiveness of the long-term performance of bridge-scour countermeasures provided by Federal Highway Administration (2012). This study focused on collecting data to assess the current condition of different bridge-scour countermeasure types, mainly armoring structures (riprap, articulated blocks, concrete armor units, and gabion mattresses). Photographs, field forms, topographic surveys, and bathymetric surveys were collected at the selected sites. The following sections outline the methods used to complete these tasks.

\section{Site Selection}

The FWHA and the USGS selected 20 bridges for this study from the National Bridge Inventory (NBI) and State Departments of Transportation databases using the following criteria:

1. The site had bridge-scour countermeasures in place that were designed according to HEC-23 guidelines.

2. The site was near an existing USGS streamgage with a daily and peak streamflow record.

3. The site had experienced a significant streamflow event since the countermeasure was installed.

Criterion 1. Although the study objective was to assess the quality and overall effectiveness of countermeasures designed to FHWA HEC-23 guidelines, some exceptions were made for sites with installed countermeasures designed to earlier versions of FHWA guidelines. Site 031, Wapsipinicon River at US-30 near Wheatland, Iowa, is one example of this exception. The extensive details provided in the bridge-scour countermeasure plans and bridge structure plans for this site made it a sufficient candidate for this study. In addition, the riprap countermeasures installed at the site in 2000 remained present around main channel piers even though it experienced several substantial floods since installation.

Criterion 2. Daily and peak streamflow data were evaluated for a representative streamgage to review the flood history after countermeasures were installed. Drainage area adjustments described in Ries (2007) were used to better estimate at-site flow conditions when a USGS streamgage and bridge site were not colocated but were on the same stream. Historical streamflow observations and flood frequency statistics were obtained from the USGS National Water Information System (U.S. Geological Survey, 2016a) and the USGS StreamStats Web application (U.S. Geological Survey, 2016b). Annual peak flow and instantaneous data were reviewed to determine the three highest unique observed peak flows since scour countermeasures were installed. Criteria for selecting unique peak flows are described in Novak (1985).

Criterion 3. Peak flow frequency statistics were reviewed for the representative streamgage using published statistics to determine if the bridge site experienced a significant streamflow event since the countermeasure was installed. Sites that experienced streamflows exceeding the 4-percent annual exceedance probability (AEP) (25-year recurrence interval) since countermeasure installation were considered significant and were included in this study. As defined by the American Society of Civil Engineers, the recurrence interval (RI) is the average interval of time within which the given flood will be equaled or exceeded once (American Society of Civil Engineers, 1953). The published statistics for a colocated or nearby streamgage were used to determine the exceedance probability of each flood event after countermeasure installation. Peak-flow frequency statistics were determined using a weighted estimate from PeakFQ and StreamStats. Site 015, Bitterroot River at Bell Crossing near Victor, MT, is one example of when weighted estimates were used. Alternatively, at-site statistics were determined using PeakFQ and Bulletin 17B estimates when published statistics were not available (Veilleux and 
others, 2014) or when peak flows exceeded the published regression limits. This method was necessary for both sites in South Carolina due to extreme flooding in 2015. Drainage area adjustments were used for peak flow frequency statistics when the streamgage and bridge were not colocated (Ries, 2007). The flood history was particularly important when assessing the effectiveness of designed countermeasures.

An additional criterion for identifying significant streamflow events was considered for bridges located in mountainous regions because the stream power and complexity of hydraulics in high-gradient streams can cause scouring at streamflows less than the 4-percent AEP. A site was selected when the bankfull discharge (typically 1-2-year RI) produced scouring comparable to the 4-percent AEP event given a specific set of basin characteristics (Holnbeck and McCarthy, 2009). Most of the selected sites in Montana met this bankfull discharge criterion and were considered to have experienced a significant streamflow event.

\section{Scour Countermeasure Assessments}

\section{Site Photographs and Field Form}

All site surveys included collecting detailed site photographs and completing a field form summarizing site characteristics. The field team collected photographs of the bridge structure, surrounding floodplain, and visible countermeasures. Photographs were documented in an annotated photo $\log$ for each site. A field form derived from Cinotto and White (2000) were completed to describe the surrounding floodplain, channel characteristics, bridge substructure, and the countermeasures. These photographic and textual descriptions may assist in future modeling efforts and survey site analyses.

\section{Bathymetric and Topographic Data}

The 20 sites selected for countermeasure assessments represented hydraulically and geographically diverse environments (fig. 1, table 1) and were divided into 9 survey categories based on specific site characteristics including depth and turbidity of water and type of riparian vegetation (tables 1 and 2). Bathymetric and topographic data were collected at each site according to appropriate methods for the survey category (table 2).

Survey categories 1 and 2 include sites requiring a manned boat to survey across large bodies of water (table 2). At the time of survey, depths at these sites generally exceeded $15 \mathrm{ft}$, suitable for using a multibeam echosounder (MBES) to acquire bathymetric data. Category 1 survey sites had clear water at the time of survey; allowing a gridded camera to be used to collect underwater images around the countermeasure if needed. Category 2 survey sites generally had turbid water that was unsuitable for underwater images.

The MBES provides high-resolution bathymetry data around submerged countermeasures. Coupled with real-time kinematic global navigation satellite systems (RTK-GNSS), the MBES is more advantageous than a single-beam echosounder (SBES), acoustic Doppler current profilers (ADCP), or other sounding methods because it provides greater coverage of the streambed to capture the bathymetry of the waterbody (Weakland and others, 2011). 
Table 2. References for various data-collection techniques of category 1-9 sites.

[MBES, multibeam echo sounder; T-LiDAR, terrestrial light detection and ranging technology; SBES, single beam echosounder; RTK-GNSS, real-time kinematic global navigation satellite system]

\begin{tabular}{|c|c|c|}
\hline Category & Data collection technique & Reference \\
\hline \multirow[t]{3}{*}{$1 / 2$} & MBES & Wood and others, 2012; Fosness, 2013; Huizinga, 2015 \\
\hline & Gridded camera & Explained in report \\
\hline & T-LiDAR & Kimbrow and Lee, 2013; Kimbrow, 2014; Brenner and others, 2016 \\
\hline \multirow[t]{5}{*}{$3 / 4$} & SBES & Snyder and others, 2016 \\
\hline & MBES & Wood and others, 2012; Fosness, 2013; Huizinga, 2015 \\
\hline & Gridded camera & Explained in report \\
\hline & T-LiDAR & Kimbrow and Lee, 2013; Kimbrow, 2014; Brenner and others, 2016 \\
\hline & Total station/RTK-GNSS & Rydlund and Densmore, 2012; Wood and others, 2012 \\
\hline \multirow[t]{2}{*}{$5 / 6$} & Total station & Wood and others, 2012 \\
\hline & T-LiDAR & Kimbrow and Lee, 2013; Kimbrow, 2014; Brenner and others, 2016 \\
\hline 7 & T-LiDAR & Kimbrow and Lee, 2013; Kimbrow, 2014; Brenner and others, 2016 \\
\hline \multirow[t]{2}{*}{8} & RTK-GNSS & Rydlund and Densmore, 2012 \\
\hline & Basic bathymetric survey & Mueller and Wagner, 2003 \\
\hline 9 & RTK-GNSS & Rydlund and Densmore, 2012 \\
\hline All & $\begin{array}{l}\text { Basic countermeasure } \\
\text { assessment field forms }\end{array}$ & Cinotto and White, 2000 \\
\hline
\end{tabular}

Motion-compensated and tripod-based terrestrial light detection and ranging technology (TLiDAR) captured high-resolution topography data for areas above the water surface and below the estimated peak flow stage. T-LiDAR technology uses rapidly moving laser pulses transmitted from the instrument. The pulses are reflected off the subject(s) and back to the instrument, which calculates the distance of the returned pulse based on the incoming velocity (Kimbrow and Lee, 2013). T-LiDAR data were generally collected around the super-structure, surrounding floodplain, bridge abutments, and piers that might be visible from the boat. Where vegetation was abundant in the area above water, RTKGNSS topographical survey methods were used. The RTK-GNSS surveys followed the techniques and methods described in Rydlund and Densmore (2012).

Underwater gridded camera systems were used to collect photographs at gridded locations around the piers and other submerged countermeasures when possible. Visual samples were used to qualitatively assess the effects of aggradation, degradation, embeddedness, and the current condition of the countermeasure. This method excelled in deep-water conditions where SBES systems could not provide sufficient data resolution and MBES was not available. However, the camera systems were only useful in clear water conditions.

Category 3 and 4 survey sites (table 2 ) had water conditions that were shallower than categories 1 and 2 survey sites, roughly 5-14 ft deep. At these sites, bathymetric data were collected with SBES or ADCP mounted to boogie-boards, small boats, and/or by wading. MBES, T-LiDAR, and RTK-GNSS were used to obtain topographic data as applicable. Sidescan technology and (or) underwater gridded cameras also were used in similar situations as conditions allowed. Category 3 survey sites had clear water at the time of survey, whereas category 4 survey sites were turbid. 
At categories 5 and 6 survey sites (table 2), the water depth was less than $4 \mathrm{ft}$ and a boat could not be used, so wading techniques were used instead. Surveyors used RTK-GNSS and total station to obtain bathymetric data and T-LiDAR, RTK-GNSS, or total station scanner systems were used to acquire topographic data. Category 5 survey sites had no vegetation that disturbed data collection, whereas obstructing vegetation existed at category 6 survey sites.

If the stream channel was dry, the site was classified as category 7 (table 2) and T-LiDAR was used to obtain all data. Category 8 survey sites (table 2) were similar to categories 3 and 4 survey sites, but were generally shallower than $4 \mathrm{ft}$ deep. Additionally, category 8 survey sites did not require detailed structural, bathymetric, or topographic surveys using T-LiDAR or MBES. Category 9 survey sites (table 2) were less than $4 \mathrm{ft}$ deep and did not require a bathymetric survey. Similar to category 8 survey sites, category 9 sites did not require detailed structural, bathymetric, or topographic surveys using T-LiDAR or MBES. Base-level assessment data included photo documentation with cross-section bathymetry data and RTK-GNSS topography data (Mueller and Wagner, 2003). These basic crosssection and countermeasure survey data will provide sufficient detail to conduct countermeasure assessments.

\section{Particle-Size Analyses}

Particle-size analyses were conducted for 21 sites with riprap countermeasures (table 3 ). Twelve of those sites are from the present study and nine of those sites are from the first phase of the project, detailed in Dudunake and others (2017). These analyses included Wolman pebble counts or highresolution bathymetric surveys to estimate above and below-water gradation of in-place riprap. Wolman pebble counts were conducted using methods developed for riprap by Federal Highway Administration (2008). Dimensions of riprap particles were measured to develop a grain-size distribution curve and will assist FHWA in verifying countermeasure design guidelines. High-resolution bathymetric surveys were conducted when wading techniques were not possible. By adjusting survey equipment settings, a highresolution, centimeter-scale bathymetric survey output was produced to assist FHWA determine riprap extent, individual rock sizes, and riprap gradation.

\section{Scour Countermeasure Assessment Data}

Countermeasure assessment results were processed, compiled, and published in a USGS Data Release for 20 sites (table 1) in Connecticut, Idaho, Iowa, Missouri, Montana, New Jersey, Pennsylvania, and South Carolina (Dudunake, 2018, https://doi.org/10.5066/F7WW7G4W). Site information for each bridge included a compressed file containing countermeasure plans, a detailed photograph log, and completed field form. Geospatial data includes all topography and bathymetry data collected and associated metadata. Site survey data includes an additional particle-size analysis for the 21 sites described in table 3 . A complete summary of geospatial data and countermeasure design plans, photo summaries, and field forms are available in Dudunake (2018). 
Table 3. Survey sites and links to particle-size analysis data for the assessment of scour-related countermeasures at representative bridges in United States, 2014-2018.

\begin{tabular}{|c|c|c|c|}
\hline $\begin{array}{l}\text { Site } \\
\text { No. }\end{array}$ & NBI structure No. & Site name & $\begin{array}{l}\text { Particle-size analysis data available at } \\
\text { https://doi.org/10.5066/F7WW7G4W }\end{array}$ \\
\hline $001^{1}$ & 500086,500087 & Apalachicola River at I-10 (SR 8), near Chattahoochee, FL & $\begin{array}{l}\text { siteID-001_ApalachicolaRiver_I- } \\
\text { 10_highres_multibeam_bathymetry.zip }\end{array}$ \\
\hline $003^{1}$ & K0932 & Mississippi River at US-54, (K0932) at Louisiana, MO & $\begin{array}{l}\text { siteID-003_MississippiRiver_US- } \\
\text { 54_highres_multibeam_bathymetry.zip }\end{array}$ \\
\hline $004^{1}$ & 1936 & Mississippi River at I-155 (A1700), near Caruthersville, MO & $\begin{array}{l}\text { siteID-004_MississippiRiver_I- } \\
\text { 155_highres_multibeam_bathymetry.zip }\end{array}$ \\
\hline $007^{1}$ & $33175(097-0003 / 0004)$ & Wabash River at I-64 (097-0003/0004), near Grayville, IL & siteID-007_WabashRiver_I-64_highres_multibeam_bathymetry.zip \\
\hline $008^{1}$ & A0906 & Thompson River at MO-6 (A0906) near Trenton, MO & siteID-008_ThompsonRiver_MO-6_wolman_pebble_count.zip \\
\hline $009^{1}$ & A4584 & Fox River at US-61 (A4584) near Wayland, MO & siteID-009_FoxRiver_US-61_wolman_pebble_count.zip \\
\hline 010 & $\begin{array}{r}000000000047594 \\
000000000047595\end{array}$ & $\begin{array}{l}\text { Perkiomen Creek and Mill Race at Salford Station Road (SR 1024) } \\
\text { near Perkiomenville, PA }\end{array}$ & siteID-010_PerkiomenCreek_SR-1024_wolman_pebble_count.zip \\
\hline 011 & 7583 & Grand River at Rte-A (P0250) near McFall, MO & siteID-011_GrandRiver_Rte-A_wolman_pebble_count.zip \\
\hline 012 & 000000000010536 & $\begin{array}{l}\text { West Branch Brandywine Creek at Strasburg Road (SR 3062) near } \\
\text { Coatesville, PA }\end{array}$ & siteID-012_BrandywineCreek_SR-3062_wolman_pebble_count.zip \\
\hline 015 & S00370000+05361 & Bitterroot River at Bell Crossing near Victor, MT & siteID-015_Bitterroot_BellCrossing_wolman_pebble_count.zip \\
\hline 016 & I00090110+01981 & Blackfoot River at I-90 at Bonner, MT & siteID-016_Blackfoot_I90_wolman_pebble_count.zip \\
\hline 020 & $\mathrm{P} 00013093+06931$ & Jefferson River at MT-2 near Three Forks, MT & siteID-020_Jefferson_ThreeForks_wolman_pebble_count.zip \\
\hline $023^{1}$ & $\mathrm{P} 00081024+0.962$ & Judith River at MT-81 near Lewistown, MT & siteID-023_Judith_wolman_pebble_count.zip \\
\hline $024^{1}$ & $\mathrm{~S} 00300000+0.2001$ & Musselshell River at S-300 at Ryegate, MT & siteID-024_Musselshell_wolman_pebble_count.zip \\
\hline $026^{1}$ & $\mathrm{P} 00003101+0.8001$ & Two Medicine River at US-89 near Browning, MT & siteID-026_TwoMedicine_wolman_pebble_count.zip \\
\hline 028 & 000000000009360 & Smith Branch at S-126 (Clement Rd) at Columbia, SC & siteID-028_SmithBranch_S-126_wolman_pebble_count.zip \\
\hline 029 & 000000000009547 & Black River at US-52 at Kingstree, SC & siteID-029_BlackRiver_US-52_wolman_pebble_count.zip \\
\hline $030^{2}$ & 000000000013660 & Upper Iowa River at IA-76 near Dorchester, IA & siteID-030_UpperIowaRiver_IA-76_wolman_highres.zip \\
\hline 031 & 000000000020740 & Wapsipinicon River at US-30 near Wheatland, IA & siteID_031_WapsipiniconRiver_US-30_wolman_pebble_count.zip \\
\hline 032 & 000000000031680 & Old Man's Creek at IA-1 near Iowa City, IA & siteID_032_OldMansCreek_IA1_wolman_pebble_count.zip \\
\hline 034 & 0216157 & Saddle River at NJ-17 at Ridgewood, NJ & siteID-034_SaddleRiver_NJ17_wolman_pebble_count.zip \\
\hline
\end{tabular}

${ }^{1}$ Site detailed in Dudunake and others (2017).

${ }^{2}$ Wolman pebble count and high-resolution bathymetry acquired. 


\section{Summary}

With the completion of bathymetric and topographical data collection, FHWA will investigate the value of their countermeasure design guidelines by simulating conditions using computer modeling analyses and the acquired survey data. A final project report will be written to summarize documentation, interpretive details, and countermeasure assessment data following the completion of the project. With the use of these surveys and scour modeling, engineers will be able to design better bridge-scour countermeasures to withstand changing stream environments using new estimates of countermeasure effectiveness.

\section{Acknowledgments}

The authors express their appreciation to the Departments of Transportation in Connecticut, Iowa, Idaho, Illinois, Missouri, Montana, New Jersey, Pennsylvania, and South Carolina for providing necessary data for each of these sites. Finally, we thank our USGS colleagues Pete Cinotto, Justin Boldt, Tom Suro, Steve Holnbeck, Sean Lawlor, Jarrett Ellis, Ben Dietsch, Justin Krahulik, Brenda Densmore, Jessica LeRoy, Rich Akins, Ben Rivers, and Ben Sleeper for their assistance with fieldwork, logistical support, and overall management of this project.

\section{References Cited}

American Society of Civil Engineers, 1953, Report of the subcommittee on the joint division committee on floods: American Society of Civil Engineers Transactions, v. 118, p. 1220-1230.

Brenner, O.T., Hapke, C.J., Lee, K.G., and Kimbrow, D.R., 2016, Terrestrial-based lidar beach topography of Fire Island, New York, June 2014: U.S. Geological Survey Data Series 980, https://dx.doi.org/10.3133/ds980.

Cinotto, P.J., and White, K.E., 2000, Procedures for scour assessments at bridges in Pennsylvania: U.S. Geological Survey Open-File Report 00-64, 210 p.

Dudunake, T.J., 2018, Geospatial data for bridge scour countermeasure assessments at select bridges in the United States, 2016-2018: U.S. Geological Survey data release, https://doi.org/10.5066/F7WW7G4W.

Dudunake, T.J., Huizinga , R.J., and Fosness, R.L., 2017, Bridge scour countermeasure assessments at select bridges in the United States, 2014-16: U.S. Geological Survey Open-File Report 2017-1048, 10 p., https://doi.org/10.3133/ofr20171048.

Federal Highway Administration, 2008, Federal Lands Highway Field Materials Manual, Appendix B: FLH Test Methods, item FLH T 521-08, Standard method of test for determining riprap gradation by wolman count, https://flh.fhwa.dot.gov/resources/materials/fmm/documents/fmm-2008.pdf.

Federal Highway Administration, 2009, Bridge scour and stream instability countermeasuresExperience, selection and design guidance-Third edition, volume 1: Hydraulic Engineering Circular, no. 23, Publication No. FHWA-NHI-09-111, 256 p.

Federal Highway Administration, 2012, Evaluating scour at bridges (5th ed.): Hydraulic Engineering Circular, No. 18, Publication No. FHWA-HIF-12-003, 340 p.

Fosness, R.L., 2013, Bathymetric surveys of the Kootenai River near Bonners Ferry, Idaho, water year 2011: U.S. Geological Survey Data Series 694, 26 p. 
Holnbeck, S.R., and McCarthy, P.M., 2009, Monitoring hydraulic conditions and scour at I-90 Bridges on Blackfoot River following removal of Milltown Dam near Bonner, Montana, in Burns, S.E., Bhatia, S.K., Avila, C.M.C., and Hunt, B.E., eds., Proceedings of 5th International Conference on Scour and Erosion: San Francisco, California, American Society of Civil Engineers, 11 p.

Huizinga, R.J., 2015, Bathymetric and velocimetric surveys at highway bridges crossing the Missouri and Mississippi Rivers on the periphery of Missouri, June 2014: U.S. Geological Survey Scientific Investigations Report 2015-5048, 81 p., https://dx.doi.org/10.3133/sir20155048.

Kimbrow, D.R., 2014, Mobile terrestrial light detection and ranging (T-LiDAR) survey of areas on Dauphin Island, Alabama, in the aftermath of Hurricane Isaac, 2012: U.S. Geological Survey Data Series 855, https://dx.doi.org/10.3133/ds855.

Kimbrow, D.R., and Lee, K.G., 2013, Erosion monitoring along the Coosa River below Logan Martin Dam near Vincent, Alabama, using terrestrial light detection and ranging (T-LiDAR) technology: U.S. Geological Survey Scientific Investigations Report 2013-5128, 7 p., https://pubs.usgs.gov/sir/2013/5128.

Lumia, Richard, 1998, Flood of January 19-20, 1996, in New York State: U.S. Geological Survey Water-Resources Investigations Report 97-4252, 61 p., https://pubs.er.usgs.gov/publication/wri974252.

Mueller, D.S., and Wagner, C.R., 2003, Field observations and evaluations of streambed scour at bridges: Federal Highway Administration Publication FHWA-RD-03-052.

National Transportation Safety Board, 1988, Collapse of New York State Thruway (1-90) bridge over the Schoharie Creek, near Amsterdam, New York, April 5, 1987: Washington, D.C., National Transportation Safety Board report NTSB/HAR-88/02, 169 p.

Novak, C.E., 1985, WRD data reports preparation guide: U.S. Geological Survey Open File Report 85480, 331 p., https://pubs.usgs.gov/of/1985/0480/report.pdf.

Ries III, K.G., 2007, The national streamflow statistics program: A computer program for estimating streamflow statistics for ungaged sites: U.S. Geological Survey Techniques and Methods 4-A6, 37 p.

Rydlund, P.H., Jr., and Densmore, B.K., 2012, Methods of practice and guidelines for using surveygrade global navigation satellite systems (GNSS) to establish vertical datum in the United States Geological Survey: U.S. Geological Survey Techniques and Methods, book 11, chap. D1, 102 p. with appendixes.

Snyder, A.G., Lacy, J.R., Stevens, A.W., and Carlson, E.M., 2016, Bathymetric survey and digital elevation model of Little Holland Tract, Sacramento-San Joaquin Delta, California: U.S. Geological Survey Open-File Report 2016-1093, 14 p., https://dx.doi.org/10.3133/ofr20161093.

U.S. Geological Survey, 2016a, National Water Information System-Web interface: U.S. Geological Survey Web site, accessed December 6, 2016, at https://waterdata.usgs.gov/nwis.

U.S. Geological Survey, 2016b, The StreamStats program: U.S. Geological Survey Web site, accessed November 18, 2016, at https://water.usgs.gov/osw/streamstats/.

Veilleux, A.G., Cohn, T.A., Flynn, K.M., Mason, R.R., Jr., and Hummel, P.R., 2014, Estimating magnitude and frequency of floods using the PeakFQ 7.0 program: U.S. Geological Survey Fact Sheet 2013-3108, 2 p.

Weakland, R.J., Fosness, R.L., Williams, M.L., and Barton, G.J., 2011, Bathymetric and sediment facies maps for China Bend and Marcus Flats, Franklin D. Roosevelt Lake, Washington, 2008 and 2009: U.S. Geological Survey Scientific Investigations Map 3150, 1 sheet.

Wood, M.S., Skinner, K.D., and Fosness, R.L., 2012, Bathymetry and capacity of Blackfoot Reservoir, Caribou County, Idaho, 2011: U.S. Geological Survey Scientific Investigations Map 3229, 1 sheet. 
Publishing support provided by the U.S. Geological Survey Science Publishing Network, Tacoma Publishing Service Center

For more information concerning the research in this report, contact the Director, Idaho Water Science Center

U.S. Geological Survey

230 Collins Rd

Boise, Idaho 83702-4520

https://www.usgs.gov/centers/id-water 
